\title{
Culturable Airborne Bacteria in Outdoor Poultry-Slaughtering Facility
}

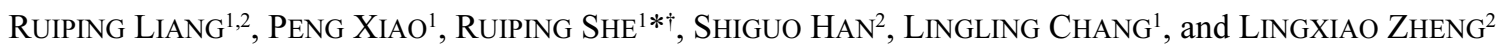 \\ ${ }^{1}$ Department of Veterinary Public Health, Key Laboratory of Zoologies of Ministry of Agriculture, College of Veterinary \\ Medicine, China Agricultural University, Beijing, 100193, China; and ${ }^{2}$ Beijing Huadu Broiler Corporations, Beijing \\ 102211, China
}

(Received October 11, 2012-Accepted January 23, 2013-Published online March 9, 2013)

\begin{abstract}
Airborne bacteria are important biological components of the aerosols and have a close relationship with human health as they can have adverse effects through infection and toxicity; higher concentrations can result in various microbial diseases. Moreover, they have a great influence on air quality in Beijing. In this study, a systematic survey on culturable airborne bacteria was carried out for 1 year at a slaughtering plant in Beijing. Bacterial samples were collected with FA-1 sampler for $3 \mathrm{~min}$, three times each day, for three consecutive days of each month from three sampling sites using BIOLOG identification technology. Results showed that Gram-positive bacteria contributed $80 \%-$ $85 \%$ and were much more prevalent than Gram-negative bacteria. Amongst 47 genera of bacteria, including 31 Grampositive bacteria and 16 Gram-negative bacteria, Micrococcus, Staphylococcus, Bacillus, Corynebacterium, and Pseudomonas were dominant, and Micrococcus, which contributed $20 \%-30 \%$, was the most dominant genus. The concentration of airborne bacteria was significantly higher in shed used to stay chicken waiting for slaughtering (SSC) and entrances to personnel and transport vehicles with products (EPV) than in green belt (GB). During the year, bacterial concentrations in summer and autumn were much higher than in winter and spring in SSC and EPV, and there were no significant variations in bacterial concentrations in GB. In different periods, a lower concentration of airborne bacteria was found at 13:00.
\end{abstract}

Key words: culturable airborne bacteria, bioaerosol, BIOLOG, dominant genus

Airborne bacteria are among the most common organisms in nature. They are considered to be correlated with air pollution and have been proposed as a cause of adverse health effects on humans (10). Elevated levels of particle air pollution have been associated with upper respiratory irritation, chronic bronchitis, organic dust toxin syndrome, or other respiratory symptoms (2).

Modern agriculture activities have changed our living environment. High microorganism pollution is a feature of many commercial slaughtering facilities. The numbers and types of microorganisms that are either bound to slaughtering facility dust or are individually airborne may play a contributing role; however, no previous studies have examined the microbial composition of a poultry slaughtering facility. Regarding their adverse effects on human health, many studies have been carried out. It was reported that airborne bacteria in pig confinement buildings in the United States, Canada, The Netherlands, Sweden, and Poland reach levels of $10^{5}$ to $10^{6} \mathrm{CFU} \mathrm{m}{ }^{-3}(1,3,4,6,8,11)$ and up to $10^{7}$ CFU $\mathrm{m}^{-3}$ in the United Kingdom (5). Gram-positive bacteria are the predominant bacteria present $(1,3,5-7,11,16)$ and microbial genera have been identified in many swine confinement units $(3-5,7,8)$. Some organisms are recognized as potential agents inducing extrinsic allergic alveolitis and causing pathogenic infection (4). The study showed that the highest median concentration of total $\left(2.0 \times 10^{7}\right.$ cells $\left.\mathrm{m}^{-3}\right)$

\footnotetext{
* Corresponding author. E-mail: sheruiping@126.com;

Tel: +86-10-62733060; Fax: +86-10-62733321.

$\uparrow$ Present address: Department of Veterinary Pathology, Key Laboratory of Zoonosis of Ministry of Agriculture College of Veterinary Medicine, China Agricultural University, Beijing, 100193, China.
}

bacteria was found in poultry houses in Switzerland (13). In subtropical Taiwan, the study quantified the levels of airborne microorganisms in six swine farms with more than 10,000 pigs, and the results showed that mean concentrations of culturable bacteria and Gram-negative bacteria were $3.3 \times 10^{5} \mathrm{CFU} \mathrm{m}^{-3}$ and $143.7 \mathrm{CFU} \mathrm{m}^{-3}$, respectively (2). A total of 1,408 cattle held in eight commercial feedlot pens were used to examine the quantity and diversity of microorganisms in cattle feedlot air (23). The results showed that only non-pathogenic Gram-positive organisms were recovered; however, Gram-negative bacteria may have been present in a viable but non-culturable state (23).

It is reported that the dominant bacteria were Micrococcus, Staphylococcus, Bacillus and Pseudomonas in the atmosphere $(15,18-20,22)$, and their concentrations differed according to location because of local environmental variables, bacterial substrates, and human activities (9). It is important to survey both the level and distribution of airborne microorganisms systematically and extensively across different outdoor environments in a poultry slaughtering facility. Three sampling sites in different functional areas were selected for research on the community structure and dynamic change of culturable bacteria in the outdoor environment of a poultry slaughtering facility. The objectives of this study were (i) to describe the groups and concentrations of airborne culturable bacteria in the outdoor environment of a poultry slaughtering facility, and (ii) to reveal the distribution characteristics and dynamic changes of bacteria concentrations at three sampling sites in the outdoor environment of a poultry slaughtering facility. 


\section{Materials and Methods}

\section{Sampling sites}

Air samples were collected from an outdoor poultry-slaughtering facility (73,000 birds slaughtered per day) situated in a suburban district of Chanping in Beijing, China, about $50 \mathrm{~km}$ from the city center. Beijing has a territorially monsoon climate and is situated in a warm temperate zone, which has a dry season from November to April and a wet season from May to October. This facility employs approximately 900 workers, operates $12 \mathrm{~h} \mathrm{~d}^{-1}$, and products 150 tons production $\mathrm{d}^{-1}$. The production is mainly exported to Japan, South Korea, Hong Kong, Central Asia, Canada, and Singapore. Three sites were selected for the study in this plant (Table 1; Fig. 1): (i) Shed used to stay chicken waiting for slaughtering (SSC), with a green area contributing to about $50 \%$ of the total area, and a few transport vehicles for chickens, with serious air pollution; (ii) Entrances to personnel and transport vehicles with products (EPV), with a small green area amounting to no more than $5 \%$ vegetation coverage and about 10 times $\mathrm{h}^{-1}$ flow of transport vehicles, and some personnel flow at commuting time, with a little air pollution; (iii) Green belt (GB), with a green area contributing to more than $95 \%$ of the total area and little flow of vehicles and personnel, with little air pollution.

\section{Sampling methods}

A six-stage culturable FA-1 sampler (imitation Andersen sampler) (Applied Technical Institute of Liaoyang, China) was used to isolate culturable bacteria from the atmosphere. Each stage includes a plate with 400 holes of uniform diameter through which air is drawn at $28.3 \mathrm{~L} \mathrm{~min}^{-1}$ to contact with Petri dishes containing agar media. AT each sampling site, the sampler was mounted $1.5 \mathrm{~m}$ above ground level on a platform. Sampling was conducted from June 2011 to May 2012. Samples were collected for $3 \mathrm{~min}$, three times (9:00, 13:00 and 17:00 hours) each day, and continued for three consecutive days of each month. For each sampling, the FA-1 sampler was

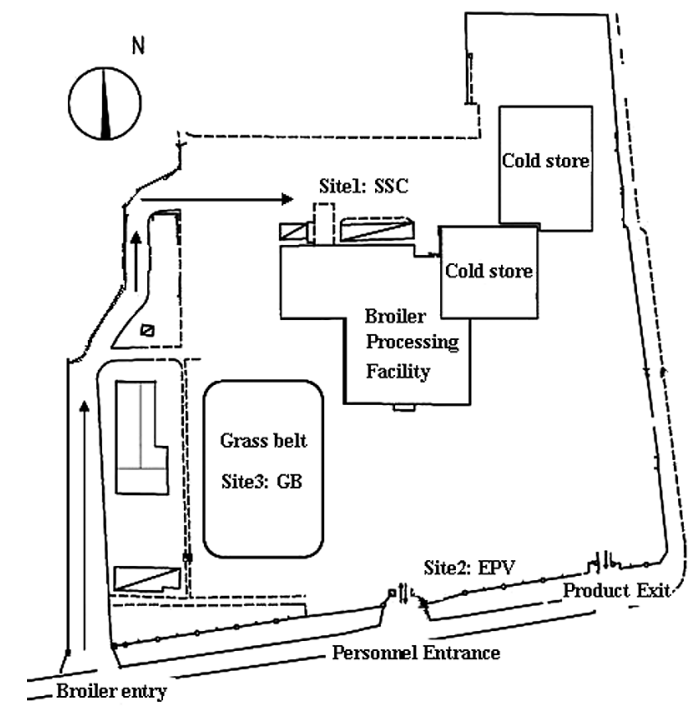

Fig. 1. Map of the plant containing the sampling sites. loaded with $9.0 \mathrm{~cm}$ Petri dishes containing Nutrient agar to culture the collected bacterial samples. Exposed culture dishes were incubated for $48 \mathrm{~h}$ at $37^{\circ} \mathrm{C}$. Results were then expressed as colonyforming units per cubic meter of air $\left(\mathrm{CFU} \mathrm{m}{ }^{-3}\right)$. $\mathrm{CFU} \mathrm{m} \mathrm{m}^{-3}$ was calculated as:

(Number of colonies $\times 1,000) /($ Sampling time $\times$ Velocity of air flow)

\section{Identification of bacteria}

Colonies were picked, further purified, Gram-stained, examined by microscopy, identified by biochemical reactions and grouped into Gram-positive cocci, Gram-positive spore bacillus, Grampositive bacteria, Gram-negative non-enteric bacteria, and Gramnegative intestinal bacteria. After a series of operation steps including purifying, Gram staining, enrichment culture, preparation of bacteria suspension and inoculating the prepared bacterial suspension into the 96 wells of the plate, Gram-positive bacteria were inoculated onto the GP plate of the 96 wells, Gram-negative bacteria were inoculated onto the GN plate of the 96 wells. They were cultured under suitable conditions according to the growth characteristics of the different types of bacteria, and then were identified to their species using the Biolog Microbial Identification System.

Biolog MicroPlates were used to test the ability of a microorganism assimilating or oxidizing compounds from a preselected panel of different carbon sources. The test yielded a characteristic pattern of reddish-orange well changes, which constituted a "metabolic fingerprint". All necessary nutrients and biochemicals were pre-filled and dried in the 96 wells of the plate. Iodonitrotetrazolium violet was used as a redox dye to colorimetrically indicate the mitochondrial activity that was stimulated during the oxidation of certain carbon sources. The MicroPlates were incubated for 16$24 \mathrm{~h}$. The pattern of reddish-orange wells was read with the Biolog MicroStation Reader to detect and quantify color responses. Biolog's MicroLog computer software automatically cross-referenced the pattern with an extensive library of species and genus. If an appropriate match was found, a presumptive identification of the isolate was made.

Biolog software can list 10 results in accordance with the matching degree of the reaction results of the 96 microplates in the database. Once the identification results match well with the database, the status bar will turn green. If the identification results are unreliable, the status bar will turn yellow and display "NOID"; however, the system will still list the 10 most likely results. Every result illustrates three important parameters, namely Probability (PROB), Similarity (SIM) and Distance (DIS). DIS and SIM are the most important values in the system; the DIS value represents the distance of testing results to the data bars in the corresponding database; the SIM value indicates the similarity of testing results to the data bars in the corresponding database. The Biolog Microbial Identification System (MIS) stipulates that when the bacterial culture time is $4-6 \mathrm{~h}$, its SIM values are $\geq 0.75$; when the culture time is 16-24 h, SIM values are $\geq 0.50$; therefore, the system can automatically show the species name based on identification results. The results show higher reliability when the SIM value is closer to 1.00 . When the SIM value is less than 0.5 , and the SIM value of the same genus name sum in the identification results is higher than 0.5 , it will automatically shows the results in the form of the genus name.

Table 1. General situation of sampling sites

\begin{tabular}{cllcc}
\hline \multirow{2}{*}{ Sampling sites } & \multicolumn{1}{c}{ Functional type } & \multicolumn{1}{c}{ Vehicle and personnel } & $\begin{array}{c}\text { Greenbelt } \\
\text { coverage rate }\end{array}$ & Air pollution \\
\hline SSC & $\begin{array}{l}\text { Shed used to stay chicken waiting for } \\
\text { slaughtering }\end{array}$ & $\begin{array}{l}\text { A few transport vehicles with chickens } \\
\text { about } 10 \text { times } \mathrm{h}^{-1}\end{array}$ & $\sim 50 \%$ & Serious air pollution \\
EPV & $\begin{array}{l}\text { Entrances to personnel and transport } \\
\text { vehicles with products }\end{array}$ & $\begin{array}{l}\text { Flow of transport vehicles, and some } \\
\text { flow of personnel at commuting time }\end{array}$ & $<5 \%$ & A little air pollution \\
GB & Green belt & Little flow of vehicles and personnel & $>95 \%$ & Little air pollution \\
\hline
\end{tabular}


Statistical analysis

Descriptive statistical analysis was performed using SPSS for Windows 10.0 (SPSS Inc., Chicago, IL, USA) by one-way analysis of variance (ANOVA).

\section{Results}

\section{Bacterial groups}

Forty-seven genera of culturable bacteria were identified from all sampling sites, including 31 Gram-positive genera at $66.0 \%$ and 16 Gram-positive genera at $34.0 \%$ (Table 2).

The dominant groups in 47 genera were Micrococcus, Staphylococcus, Bacillus, Corynebacterium and Pseudomonas successively. These five dominant groups occupied about $50 \%$ of the total culturable bacteria, with Micrococcus at $20-30 \%$ and Pseudomonas at $2.5-5.0 \%$.

Within the dominant groups, Micrococcus had the maximum bacterial concentration percentage and accounted for $32.5 \%$ at the EPV, $26.6 \%$ in the SSC, and $20.5 \%$ in the GB, respectively.

Staphylococcus was the second most common group isolated from samples, followed by Bacillus, Corynebacterium and Pseudomonas. Their concentration percentages varied from $2.82 \%$ to $16.28 \%$.

The concentration percentages of Micrococcus $(P<0.05)$ and Bacillus $(P<0.05)$ were significantly higher at EPV than in the GB and SSC; however, the concentration percentages of Staphylococcus $(P<0.01)$ and Pseudomonas $(P<0.05)$ were significantly higher in the GB than in the SSC and at the EPV, and no significant differences in concentration percentages in other groups were found at any sampling sites.

\section{Bacterial concentration}

Overall concentration

Considering all sampling sites, the concentration range of culturable bacteria was $48-27,920 \mathrm{CFU} \mathrm{m}^{-3}$ and the mean

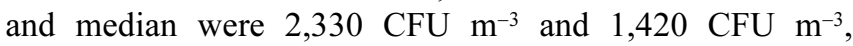
respectively (Table 3 ). Significantly higher bacterial concentrations were found in the SSC and at the EPV than in the GB $(P<0.05)$. The mean concentration was $2,714 \mathrm{CFU} \mathrm{m}^{-3}$ $\left(142-17,876 \mathrm{CFU} \mathrm{m}^{-3}\right)$ in the SSC, 2,664 CFU m ${ }^{-3}(188$ $\left.27,920 \mathrm{CFU} \mathrm{m}^{-3}\right)$ at the EPV and 1,582 $\mathrm{CFU} \mathrm{m}^{-3}(48-10,658$ CFU $\mathrm{m}^{-3}$ ) in the GB (Table 3).

The concentrations of Micrococcus and Bacillus in the SSC and at the EPV were higher than in the GB $(P<0.01)$, but no significant difference was found between the SSC and the EPV $(P>0.05)$. Concerning Staphylococcus, the lowest concentration was observed at the EPV $(P<0.01)$; however, there were no significant differences in Corynebacterium and Pseudomonas concentrations at any sampling sites $(P>0.05$; Fig. 2).

\section{Seasonal concentration}

Significant differences in bacterial concentrations among seasons existed in the SSC and the EPV, where the mean concentrations were higher in summer (June to August) and autumn (September to November), and lower in spring (March to May) and winter (December to February) $(P<0.01)$, while no significant variation of bacterial concentrations was observed in different seasons in the GB $(P>0.05)$. At the
Table 2. Culturable airborne bacterial populations collected by FA-1 sampler

\begin{tabular}{|c|c|c|c|}
\hline \multirow{2}{*}{ Functional areas/genera/species } & \multicolumn{3}{|c|}{ Functional area } \\
\hline & SSC (\%) & EPV (\%) & GB (\%) \\
\hline Gram-positive & 82.3 & 83.7 & 86.8 \\
\hline Actinomyces & 1.21 & 0.41 & 0.39 \\
\hline Aerococcus & 0.4 & 0.41 & - \\
\hline Arcanobacterium & - & 1.22 & 1.16 \\
\hline Arthrobacter & 1.21 & 0.81 & 0.39 \\
\hline Bacillus & 5.65 & 8.94 & 6.2 \\
\hline Brevibacterium & 2.82 & 5.28 & 3.1 \\
\hline Camobacterium & 1.21 & 0.81 & 0.39 \\
\hline Cellulomonas & 0.81 & 1.22 & 1.55 \\
\hline Cellulodimicrobium & 0.4 & 1.22 & 0.78 \\
\hline Clavibacter & 0.81 & 0.41 & 1.94 \\
\hline Corynebacterium & 3.23 & 4.88 & 3.88 \\
\hline Curtobacterium & 2.81 & 1.63 & 1.55 \\
\hline Deinococcus & 1.98 & - & 0.78 \\
\hline Dermabacter & 0.4 & - & - \\
\hline Enterococcus & 0.4 & 0.41 & 0.78 \\
\hline Gardnerella & - & 0.41 & - \\
\hline Gemella & 0.4 & - & 1.94 \\
\hline Gordonia & 0.81 & 2.03 & 0.39 \\
\hline Kocuria & 0.4 & 1.22 & - \\
\hline Kurthia & - & - & 0.39 \\
\hline Kytococcus & 0.81 & 0.81 & - \\
\hline Leuconostoc & 0.4 & - & - \\
\hline Macrococcus & 2.02 & 1.63 & 1.55 \\
\hline Microbacterium & 2.02 & 1.63 & 4.26 \\
\hline Micrococcus & 26.61 & 35.52 & 20.54 \\
\hline Pediococcus & 1.21 & 0.41 & 1.94 \\
\hline Rathaybacter & 0.4 & - & - \\
\hline Rhodocococcus & 0.4 & 2.03 & 1.94 \\
\hline Staphylococcus & 10.48 & 8.94 & 16.28 \\
\hline Streptococcus & 1.21 & 1.22 & 0.39 \\
\hline Vagococcus & 4.03 & 0.41 & 3.1 \\
\hline No identification & 7.66 & 2.85 & 10.85 \\
\hline Gram-negative & 17.7 & 16.3 & 13.2 \\
\hline Achromobacter & - & - & 0.78 \\
\hline Acinetobacter & 0.81 & 0.41 & - \\
\hline Aeromonas & 1.61 & - & - \\
\hline Brevundimonas & 0.81 & - & 0.78 \\
\hline Buttiauxella & 0.4 & 0.41 & - \\
\hline Escherichia & - & 0.41 & - \\
\hline Flavobacterium & 0.4 & - & - \\
\hline Pantoea & 0.81 & 1.63 & 1.94 \\
\hline Pasteurella & 2.02 & 0.81 & - \\
\hline Phyllobacterium & - & - & 0.39 \\
\hline Pseudomonas & 2.82 & 4.47 & 5.04 \\
\hline Rahnella & 0.4 & 0.41 & 0.39 \\
\hline Ralstonia & - & - & 0.39 \\
\hline Vibrio & 0.8 & 2.03 & 1.16 \\
\hline Xanthomonas & - & 0.41 & - \\
\hline Yersinia & - & - & 0.39 \\
\hline No identification & 6.85 & 5.28 & 1.94 \\
\hline
\end{tabular}

three sampling sites, there were no significant differences in bacterial concentrations between spring and winter $(P>0.05)$. In the SSC and EPV, the concentration was highest during autumn $(P<0.01)$, accounting for 5,975.3 CFU $\mathrm{m}^{-3}$ and 3,866.5 CFU m ${ }^{-3}$, respectively (Fig. 3). 
Table 3. Concentration data for total airborne bacteria at the three sampling sites

\begin{tabular}{lcccc}
\hline $\begin{array}{c}\text { Sampling } \\
\text { site }\end{array}$ & $\begin{array}{c}\text { Mean } \\
\left(\mathrm{CFU} \mathrm{m}^{-3}\right)\end{array}$ & $\begin{array}{c}\text { Median } \\
\left(\mathrm{CFU} \mathrm{m}^{-3}\right)\end{array}$ & $\begin{array}{c}\text { Minimal level } \\
\left(\mathrm{CFU} \mathrm{m}^{-3}\right)\end{array}$ & $\begin{array}{c}\text { Maximal level } \\
\left(\mathrm{CFU} \mathrm{m}^{-3}\right)\end{array}$ \\
\hline $\mathrm{SSC}$ & 2,714 & 1,546 & 142 & 17,876 \\
$\mathrm{EPV}$ & 2,664 & 1,676 & 188 & 27,920 \\
$\mathrm{~GB}$ & 1,582 & 1,172 & 48 & 10,658 \\
General & 2,330 & 1,420 & 48 & 27,920 \\
\hline
\end{tabular}

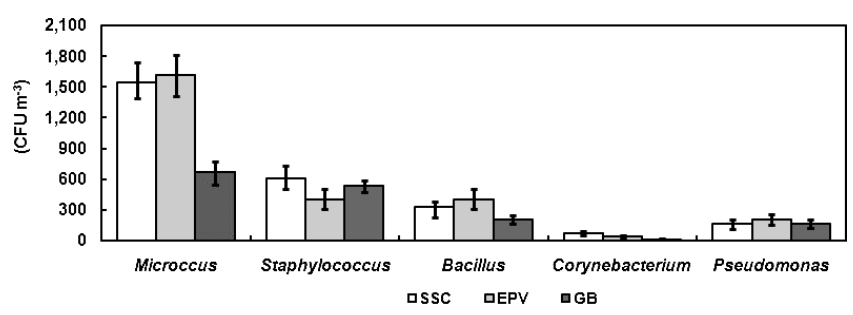

Fig. 2. Dominant bacterial concentration at the three sampling sites.

\section{Monthly concentration}

The total bacteria concentrations from June to October were higher than in other months in the SSC and EPV $(P<0.05 ;$ Fig. 4). The highest concentration was recorded in October $\left(12,047 \mathrm{CFU} \mathrm{m}^{-3}\right)$ in the SSC and in June $(6,514$

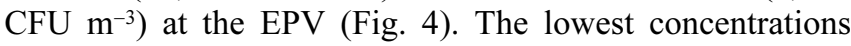
were found in April in the SSC $\left(1,286 \mathrm{CFU} \mathrm{m}^{-3}\right)$ and EPV $\left(1,380 \mathrm{CFU} \mathrm{m}^{-3}\right)$; however, the concentrations exhibited no significant differences at the EPV throughout the year. At all sampling sites, no significant variations in bacteria concentrations were found from November to May $(P>0.05$; Fig. 4). The same variations were observed between Micrococcus concentrations and total bacterial concentrations at the three sampling sites during the year. The highest concentration of

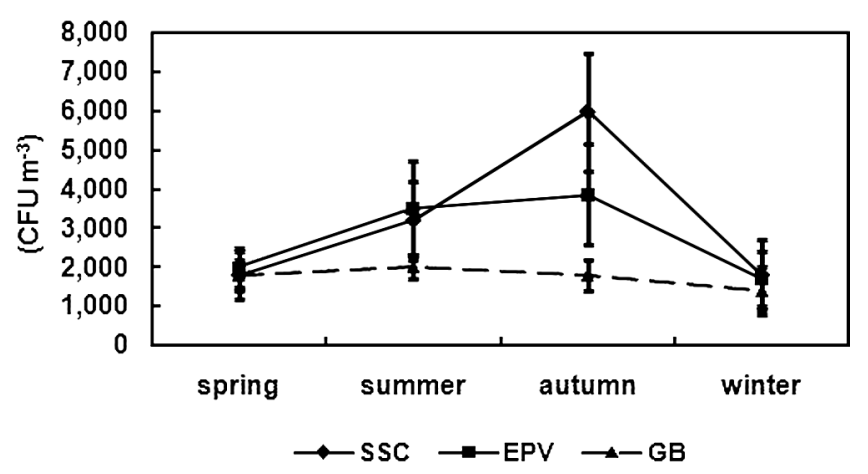

Fig. 3. Seasonal variation patterns of the airborne concentration of total culturable bacteria.

Micrococcus was recorded in October $\left(3,205 \mathrm{CFU} \mathrm{m}^{-3}\right)$ in the SSC and in June $\left(2,313 \mathrm{CFU} \mathrm{m}^{-3}\right)$ at the EPV. The lowest concentration was found in April $\left(342 \mathrm{CFU} \mathrm{m}^{-3}\right)$ in the SSC and GB (490 $\left.\mathrm{CFU} \mathrm{m}^{-3}\right)$. At all sampling sites, for Staphylococcus, the concentration levels in December and April were relatively lower than in other months; however, no significant variations in Corynebacterium and Pseudomonas concentrations were observed during the year at any sampling sites. The same variations were observed in Bacillus except for the higher concentration in September in the SSC (Fig. 4).

\section{Diurnal changes at three sampling times}

Total bacterial concentration was lower at 13:00 than at 9:00 and 15:00 at different sampling sites (Fig. 5). In the SSC, the concentration was higher at 9:00 $(P<0.05)$ and 17:00 $(P<0.05)$ than at 13:00. At the EPV, the concentration was higher at 9:00 $(P<0.05)$ than at 13:00. No significant difference at the three sampling times existed in the GB $(P>0.05)$. The highest concentrations of Micrococcus were
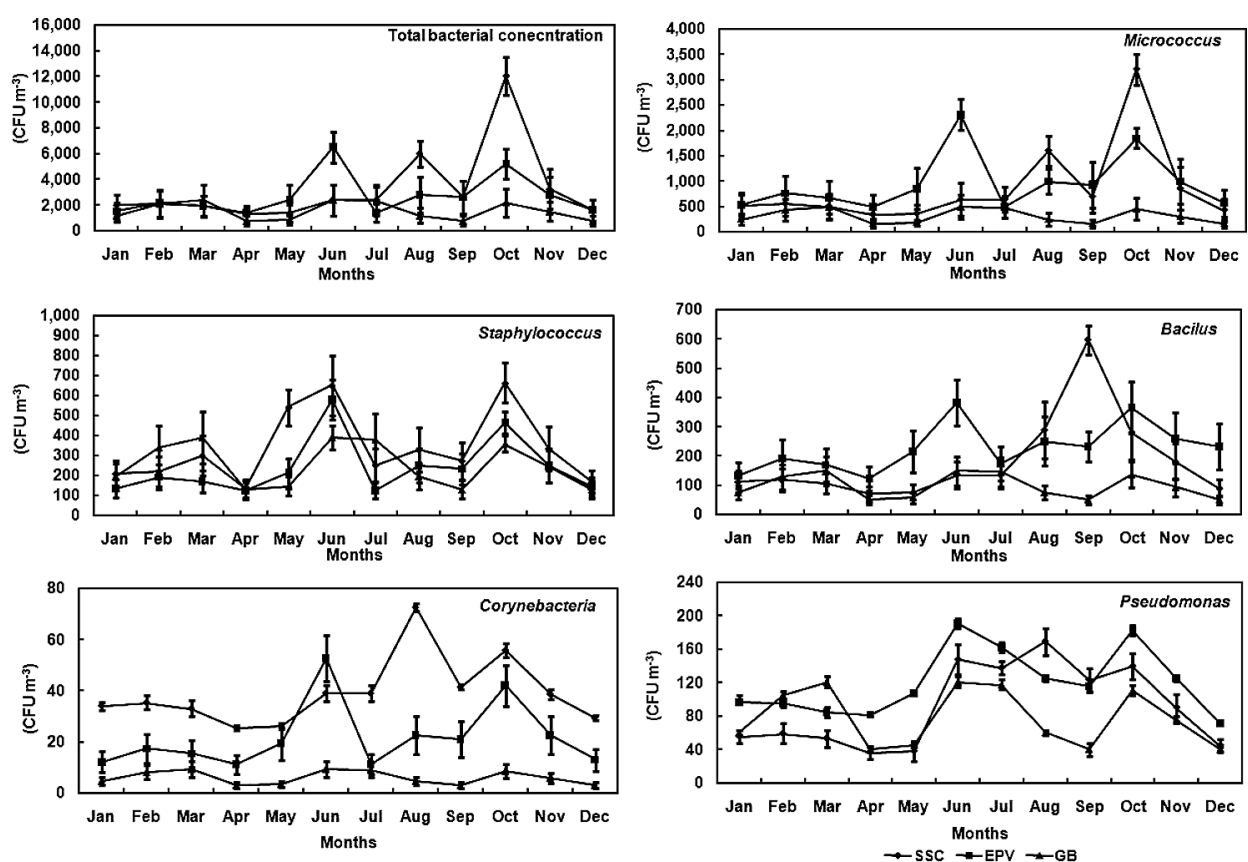

Fig. 4. Monthly variation pattern of the airborne concentration of culturable bacteria at the three sampling sites. 


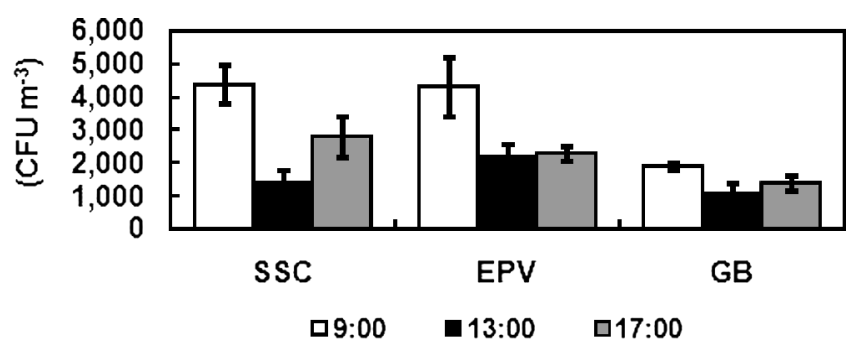

Fig. 5. Diurnal changes of total bacterial concentration at three sampling times in a day.
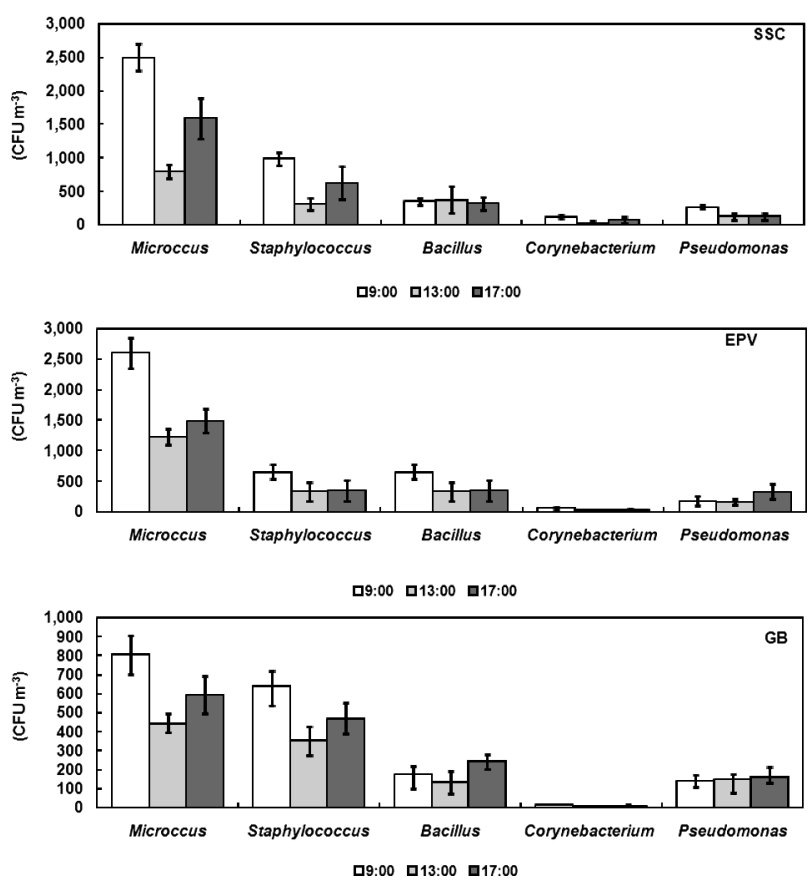

Fig. 6. Diurnal changes of bacterial group concentration at three sampling times in a day.

recorded at 9:00 $(P<0.05)$, and the lowest concentration of Staphylococcus was found at 13:00 at all sampling sites $(P<0.05$; Fig. 6).

\section{Discussion}

In general, the bacterial concentration in the slaughtering facility was higher than in studies conducted in other functional areas (21), which could lead to serious microbial pollution in the atmosphere. The bacterial concentrations in the atmosphere varied greatly at different sampling sites during a year at the plant, and the wide range of concentrations could be attributed to the micro-environmental and meteorological conditions, sampling time during the day and year, and different climatic conditions during the year (17). In other studies, there were large differences in total bacterial concentrations and marked variations were also found in cities in other countries $(2,14)$. For example, Katja et al. (13) reported the highest median concentrations of total $\left(2.0 \times 10^{7} \mathrm{CFU} \mathrm{m}^{-3}\right)$ and bacteria $\left(4.4 \times 10^{5} \mathrm{CFU} \mathrm{m}^{-3}\right)$ in Swiss poultry houses. These marked differences could be attributed to the geographic location, different bacterial growth sub- strates in different countries, as well as different types of sampler and media and different sampling methods used by the researchers (10).

The prevalent bacterial groups from all the sampling sites were Micrococcus, Staphylococcus, Bacillus, Corynebacterium and Pseudomonas, some of which have been reported as the most common airborne bacteria in different environments in other studies $(10,12,13,25)$. Micrococcus, comprising more than one third of the collected samples, was the most dominant bacterial group in the present study; however, it was reported that Staphylococcus and Bacillus were the most dominant bacterial group in open-air swine houses in Spain (14).

A significantly high concentration of airborne bacteria was observed in SSC and EPV in summer and in autumn at this plant. On one hand, air temperature and moisture in the microenvironment in summer and autumn could be adaptable for the germination, growth and propagation of airborne bacteria. On the other hand, frequent personnel flow and vehicle transportation with product and chickens might also result in increased bacterial concentration in the atmosphere. The highest concentration of airborne bacteria was observed in autumn. In summer, vegetation flourishes and vegetative exudates could kill some bacteria (24) released into the atmosphere under certain conditions, so the bacterial concentration was relative lower than in autumn. In spring, vegetation does not flourish because of the climatic conditions in Beijing, and withered away in winter. There were insufficient growth substrates for bacteria in the atmosphere around the facility, and no significant differences in bacterial concentration were found among the three sampling sites in spring and winter.

Moreover, frequent personnel flow and vehicle transportation with product and chickens might also result in increased bacterial concentration in the atmosphere; therefore, due to vehicles transporting chickens with some bacteria, the highest bacterial concentration was observed in SSC. In GB, a low concentration of airborne bacteria was recorded, which might be attributed to high vegetation coverage, fewer activities such as personnel flow and vehicle transportation and many other environmental factors inhibiting the growth of bacteria. No significant seasonal variation in bacteria concentration was recorded during the year in GB.

Studies showed that some airborne bacteria showed seasonality, corresponding to their seasonal occurrence. Micrococcus was predominant during autumn and Staphylococcus during summer, while Bacillus species were predominant during autumn (17) but no such variation was found in the present study; however, concentration variations of different bacterial groups were found during the year. The variation of Bacillus concentration was opposite that of Micrococcus and Staphylococcus. In different environments, despite the similarity of the bacterial community composition, there was a great discrepancy in the concentration percentages. This demonstrated that the concentration percentages of bacterial groups changed with the environmental and sampling conditions.

In the present study, higher concentrations of Micrococcus and Staphylococcus were recorded at 9:00 $(P<0.05)$, and a lower concentration was found at 13:00 $(P<0.05)$. These 
results were consistent with the previous study. Shaffer reported that the bacterial concentration increased at dawn, then decreased to noon and increased gradually to sunset (25).

In this study, the level of airborne bacteria was investigated comprehensively and systematically among sites at a poultryslaughtering facility and identified highly contaminated areas at this outdoor facility. In these high-contaminated areas, we should take effective measures to control air pollution, improve environment quality and then protect the health of the personnel. The study has important theoretical and practical significance for air pollution control and improvement of the quality of the environment. Further research is required to identify the level of other biological particles, such as fungi, actinomycetes, viruses and so on at the poultry-slaughtering facility to evaluate airborne microbial communities comprehensively.

\section{Conclusions}

In this study, an investigation of airborne bacteria at an outdoor slaughtering facility was conducted in Beijing. It can be concluded that (i) the prevalent bacterial groups from all the sampling sites were Micrococcus, Staphylococcus, Bacillus, Corynebacterium and Pseudomonas. The genus of highest concentration was Micrococcus; (ii) In different areas, despite the similarity of the bacterial community composition, there was a great discrepancy among the concentration percentages; (iii) There was high bacterial concentration in areas with high vehicle transportation and personnel flow, where the concentration of airborne bacteria might vary according to the seasonal occurrence and was higher in summer and autumn, but lower in spring and winter.

\section{Acknowledgements}

The authors gratefully acknowledge Beijing Huadu Broiler Corporation for collecting the samples. The authors also thank graduate students, colleagues and teachers who provided their valuable suggestions to our research group and personnel in the Department of Quality Controlling at Beijing Huadu Broiler Corporation.

\section{References}

1. Attwood, P., R. Brouwer, P. Ruigewaard, P. Versloot, R. de Wit, D., and Heederik, J.S. Boleij. 1987. A study of the relationship between airborne contaminants and environmental factors in Dutch swine confinement buildings. Am. Ind. Hyg. Assoc. J. 48:745-751.

2. Chang, C.W., H. Chung, C.F. Huang, H., and J. Su. 2001. Exposure of workers to airborne microorganisms in open-air swine house. Appl. Environ. Microbiol. 67:155-161.

3. Clark, S., R. Rylander, and L. Larsson. 1983. Airborne bacteria, endotoxin and fungi in dust in poultry and swine confinement buildings. Am. Ind. Hyg. Assoc. J. 44:537-541.

4. Cormier, Y., G. Tremblay, A. Meriaux, G. Brochu, and J. Lavoie. 1990. Airborne microbial contents in two types of swine confinement buildings in Quebec. Am. Ind. Hyg. Assoc. J. 51:304-309.
5. Crook, B., J.F. Robertson, S.A. Travers Glass, E.M. Botheroyd, J. Lacey, and M.D. Topping. 1991. Airborne dust, ammonia, microorganisms, and antigens in pig confinement houses and the respiratory health of exposed farm workers. Am. Ind. Hyg. Assoc. J. 52:271-279.

6. Donham, K., P. Haglind, Y. Peterson, R. Rylander, and L. Belin. 1989. Environmental and health studies of farm workers in Swedish swine confinement buildings Brit. Am. J. Ind. Med. 46:31-37.

7. Donham, K.J., W. Popendorf, U. Palmgren, and L. Larsson. 1986. Characterization of dusts collected from swine confinement buildings. Am. J. Ind. Med. 10:294-297.

8. Elliott, L.F., T.M. Mccalla, and J.A. Deshazer. 1976. Bacteria in the air of housed swine units. App. Environ. Microbiol. 32:270-273.

9. Hameed, A.A.A., and M.I. Khodr. 2001. Suspended particulates and bioaerosols emitted from an agricultural non-point source. J. Environ. Monit. 3:206-209.

10. Hargreaves, M., S. Parappukkaran, L. Morawska, J. Hitchins, C. He, and D. Gilbert. 2003. A pilot investigation into association between indoor airborne fungal and non-biological particle concentrations in residential houses in Brisbane, Australia. Sci. Total Environ. 312:89101.

11. Heedreick, D., R. Brouwer, K. Biersteker, and J.S.M. Boleij. 1991. Relationship of airborne endotoxin and bacteria levels in pig farms with the lung function and respiratory symptoms of farmers. Int. Arch. Occ. Env. Hea. 62:595-601.

12. Huang, C.Y., C.C. Lee, F.C. Li, Y.P. Ma, and H.J.J. Su. 2002. The seasonal distribution of bioaerosols in municipal landfill sites: a 3-yr study. Atmos. Environ. 36:4385-4595.

13. Katja, R., D. Brigitta, I. Martin, M. Eduard, W. Christoph, H. Jörg, J.D. Kelley, P. Urban, and N. Dennis. 2002. Air contaminants in different European farming environments. Ann. Agr. Env. Med. 9:41-48.

14. Lazaro, J., T. Ferrer, J. Caro, C. Gargallo, C. Asensio, and A. Moure. 2000. An aerobiological study in the rural areas of Aragon with a high population of pigs. Grana 39:259-265.

15. Liu, L., M. Krahmer, A. Fox, C. Feigley, A. Featherstone, A. Saraf, and L. Larsson. 2000. Investigation of the concentration of bacteria and their cell envelope components in indoor air in two elementary schools. J. Air Waste Manage. Assoc. 50:1957-1967.

16. Mackiewicz, B. 1998. Study on exposure of pig farm workers to bioaerosols, immunologic reactivity and health effects. Ann. Agr. Env. Med. 5:169-175.

17. Mancinelli. R., and W. Shulls. 1978. Airborne bacteria in an urban environment. Appl. Environ. Microbiol. 35:1095-1101.

18. Pastuszka, J., U. Paw, D. Lis, and A. Wlazlo. 2000. Bacterial and fungal aerosol in indoor environment in Upper Silesia, Poland. Atmos. Environ. 34:3833-3842.

19. Sarica, S., A. Asan, M. Otkun, and M. Ture. 2002. Monitoring indoor airborne and bacteria in the different areas of Trakya University Hospital, Edime, Turkey. Indoor Built Environ. 11:285-292.

20. Seino, K., T. Takano, and K. Nakamura. 2005. An evidential example of airborne bacteria in a crowded, underground public concourse in Tokyo. Atmos. Environ. 24:624-634.

21. Shaffer, B., and B. Lighthart. 1997. Survey of culturable airborne bacteria at four diverse locations in Oregon: urban, rural, forest, and coastal. Microb. Ecol. 34:167-177.

22. Shintani, H., E. Taniai, and A. Miki. 2004. Comparison of the collecting efficiency of microbiological air samplers. J. Hosp. Infect. 56:42-48.

23. Wilson, S.C., J. Morrow-Tesch, D.C. Straus, J.D. Cooley, W.C. Wong, F.M. Mitlohner, and J.J. McGlone. 2002. Airborne microbial flora in a cattle feedlot. Appl. Environ. Microbiol. 68:3238-3242.

24. Xie, H.L., S.R. Li, and X.Y. Yuan. 1999. Study on the disinfection of plant volatile secretion to the microorganism content in the air. J. Henan Agric. Univ. 33:127-133.

25. Zucker, B.A., S. Trojan, and W. Muller. 2000. Airborne gramnegative bacterial flora in animal houses. J. Vet. Med. B. 47:37-46. 